\title{
The need for an organized ECMO-based respiratory program in Japan
}

\author{
Satoru Hashimoto
}

Received: 8 June 2012/Accepted: 14 June 2012/Published online: 14 July 2012

(C) Japanese Society of Anesthesiologists 2012

Keywords ECMO $\cdot$ Acute lung injury $\cdot$ H1N1 influenza

Extracorporeal membrane oxygenation (ECMO) is an expanded clinical application of cardiopulmonary bypass originally introduced in the mid 1950s, which allowed a longer period of support than the standard bubble and film type oxygenator and rapidly gained acceptance in cardiothoracic surgery. It was, therefore, logical to use ECMO temporarily in patients presenting with acute life-threatening hypoxemia. In a review published in 1973, Lefrak et al. [1] reported a $15 \%$ survival rate in 41 patients with refractory hypoxemia treated with membrane oxygenation. An identical survival rate was found by Gille and Bagniewski [2], in 233 patients with acute respiratory distress syndrome (ARDS) treated with ECMO between 1966 and 1975. However, in the randomized study by Zapol et al. [3], in patients presenting with respiratory distress, the survival among 42 patients assigned to ECMO was only $9.5 \%$, compared with $8.3 \%$ in 48 patients assigned to standard mechanical ventilation. In a study published in 1994, of 40 patients suffering from severe ARDS, Morris et al. [4] reported a $33 \%$ survival rate among the 21 patients randomly assigned to veno-venous ECMO for the extracorporeal removal of $\mathrm{CO}_{2}$, versus $42 \%$ among the 19 patients assigned to mechanical ventilation. In 1996, a large randomized trial in the United Kingdom found ECMO effective

This comment refers to the article available at doi:10.1007/s00540-012-1402-x.

\section{S. Hashimoto $(\square)$}

Department of Anesthesiology and Intensive Care Medicine, Kyoto Prefectural University of Medicine, 465 Kajiicho, Kawaramachi-Hirokoji, Kamigyo-ku, Kyoto 602-8566, Japan e-mail: satoru@koto.kpu-m.ac.jp in neonates presenting with severe, though potentially reversible, respiratory failure. Thereafter, the enthusiasm for using ECMO for respiratory distress seemed to wane, except for its use in neonates or for lung transplantation. By 2008, over 21,500 neonates had been treated with ECMO worldwide, of whom $76 \%$ survived to hospital discharge [5]. Meanwhile, among the few medical centers that continued to use ECMO for severe ARDS, 2 institutions, in the United States and Sweden, reported survival rates of $54 \%$ in 100 patients and $76 \%$ in 16 patients, respectively $[6,7]$. The Extracorporeal Life Support Organization reported retrospective, uncontrolled data collected from 1986 to 2006 in 1,473 adults with severe respiratory failure treated with ECMO, whose median age was 34 years, and of whom $50 \%$ survived to discharge from the hospital [8]. In that analysis, veno-venous bypass was associated with a higher survival than veno-arterial bypass. The conventional ventilatory support versus extracorporeal membrane oxygenation for severe adult respiratory failure (CESAR) trial, conducted in the United Kingdom between 2001 and 2006, showed that the transfer of adults with severe but potentially reversible respiratory failure, whose Murray score exceeded 3.0 or who had a $\mathrm{pH}$ of $<7.20$ on optimal conventional therapy, to a center with an ECMO-based management protocol, improved the survival significantly without severe residual disability [9]. In the ECMO-assigned group 57 of 90 patients (63\%) survived, compared with 41 of $87(47 \%)$ in the conventional management group. Of the 90 patients assigned to the ECMO group, 68 did undergo ECMO, while 19 of the 22 remaining patients were transferred to an ECMO center and were managed by lung protective measures. While it was argued that the exclusion of the 22 patients who did not undergo ECMO would have canceled its positive effect, this study did show that transfer of patients to an ECMO center improved the clinical outcome. 
The use of ECMO for adult respiratory failure had, nevertheless, not attracted global attention until the outbreak of a new type of influenza in 2009. After the first report, in April 2009, of severe pneumonia due to the swine influenza A virus (H1N1) in Mexico [10], the worldwide pandemic spread rapidly. While this strain is not virulent in the elderly, many young patients developed pneumonia refractory to mechanical ventilation, requiring ECMO as a last resort. In Australia and New Zealand, between June 1 and August 31, 2009, 722 patients were admitted to 187 intensive care units (ICUs) for the management of severe respiratory failure due to influenza (representing 28.7 cases $/ 10^{6}$ population [10]), of whom 68 were treated with ECMO for 7-15 days in 15 ICUs [11]. Among these 68 patients, $53(78 \%)$ were weaned from ECMO, and 48 survived to the time of reporting [11]. Most patients supported by ECMO were $>18$ years of age, though the median age was only 36 years [11]. Several strongly positive reports followed, most of which described the effectiveness of ECMO and the organization of a patient transfer system to an ECMO center [12-15].

In this issue of the Journal of Anesthesia, Takeda et al. [16], report the results of a Japanese observational study of severe respiratory failure due to $\mathrm{H} 1 \mathrm{~N} 1$ in patients treated with ECMO, in which the survival rate of 14 patients to hospital discharge was a disappointing $36 \%$. Why was the rate so low? Probably not because of the delivery of inferior medical care, as the Japanese standards are generally high. Among several other explanations, the first seems to be the limited experience with ECMO of most participants in that study, and the absence of routine practice, as the 14 patients were treated in 12 separate ICUs. Second, Japan does not have an organized ECMO network or an experienced referral center. Third, the monitoring system and equipment available in Japan is generally not suitable for the delivery of ECMO for longer than approximately 1 week. Finally, in several cases, ECMO was initiated after more than 1 week of mechanical ventilation.

The last outbreak of H1N1 in Japan was, fortunately, not major, and mortality was limited. However, this country must prepare for the next outbreak, which, besides being unpredictable, might be more serious. There is no firm evidence that ECMO is superior to other therapies, and protocols vary widely among medical centers. While the criteria for its implementation have not been formulated, one might consider ECMO when $\mathrm{PaO}_{2}$ falls below $50 \mathrm{mmHg}$ despite maximal ventilator support, i.e., fraction of inspired oxygen $\left(\mathrm{FiO}_{2}\right)$ of 1.0 and positive end expiratory pressure (PEEP) of $20 \mathrm{~cm} \mathrm{H} \mathrm{H}_{2} \mathrm{O}$, with the assistance of neuromuscular blockade. The aim of ECMO is to facilitate the use of protective ventilation, which may allow lower $\mathrm{FiO}_{2}$, tidal volume, and peak inspiratory pressure. This so-called "lung rest" might be a key strategy to prevent further ventilator-associated lung injury, as many survivors fully recovered their lung function after ECMO therapy.

This study by Takeda et al. shows the critical importance of putting in place a fully functional ECMO system before the next pandemic hits Japan.

\section{References}

1. Lefrak EA, Stevens PM, Noon GP, DeBakey ME. Current status of prolonged extracorporeal membrane oxygenation for acute respiratory failure. Chest. 1973;63:773-82.

2. Gille JP, Bagniewski AM. Ten years of use of extracorporeal membrane oxygenation (ECMO) in the treatment of acute respiratory insufficiency (ARI). Trans Am Soc Artif Intern Organs. 1976;22:102-9.

3. Zapol WM, Snider MT, Hill JD, Fallat RJ, Bartlett RH, Edmunds LH, Morris AH, Peirce EC 2nd, Thomas AN, Proctor HJ, Drinker PA, Pratt PC, Bagniewski A, Miller RG Jr. Extracorporeal membrane oxygenation in severe acute respiratory failure. A randomized prospective study. JAMA. 1979;242:2193-6.

4. Morris AH, Wallace CJ, Menlove RL, Clemmer TP, Orme JF Jr, Weaver LK, Dean NC, Thomas F, East TD, Pace NL, Suchyta MR, Beck E, Bombino M, Sittig DF, Bohm S, Hoffmann B, Becks H, Butler S, Pearl J, Rasmusson B. Randomized clinical trial of pressure-controlled inverse ratio ventilation and extracorporeal $\mathrm{CO}_{2}$ removal for adult respiratory distress syndrome. Am J Respir Crit Care Med. 1994;149:295-305.

5. Frenckner B, Radell P. Respiratory failure and extracorporeal membrane oxygenation. Semin Pediatr Surg. 2008;17:34-41.

6. Kolla S, Awad SS, Rich PB, Schreiner RJ, Hirschl RB, Bartlett RH. Extracorporeal life support for 100 adult patients with severe respiratory failure. Ann Surg.1997;226:544-64 (discussion 65-6).

7. Linden V, Palmer K, Reinhard J, Westman R, Ehren H, Granholm T, Frenckner B. High survival in adult patients with acute respiratory distress syndrome treated by extracorporeal membrane oxygenation, minimal sedation, and pressure supported ventilation. Intensive Care Med. 2000;26:1630-7.

8. Brogan TV, Thiagarajan RR, Rycus PT, Bartlett RH, Bratton SL. Extracorporeal membrane oxygenation in adults with severe respiratory failure: a multi-center database. Intensive Care Med. 2009;35:2105-14.

9. Peek GJ, Mugford M, Tiruvoipati R, Wilson A, Allen E, Thalanany MM, Hibbert CL, Truesdale A, Clemens F, Cooper N, Firmin RK, Elbourne D. Efficacy and economic assessment of conventional ventilatory support versus extracorporeal membrane oxygenation for severe adult respiratory failure (CESAR): a multicentre randomised controlled trial. Lancet. 2009;374: 1351-63.

10. Webb SA, Pettila V, Seppelt I, Bellomo R, Bailey M, Cooper DJ, Cretikos M, Davies AR, Finfer S, Harrigan PW, Hart GK, Howe B, Iredell JR, McArthur C, Mitchell I, Morrison S, Nichol AD, Paterson DL, Peake S, Richards B, Stephens D, Turner A, Yung M. Critical care services and 2009 H1N1 influenza in Australia and New Zealand. N Engl J Med. 2009;361:1925-34.

11. Davies A, Jones D, Bailey M, Beca J, Bellomo R, Blackwell N, Forrest P, Gattas D, Granger E, Herkes R, Jackson A, McGuinness S, Nair P, Pellegrino V, Pettila V, Plunkett B, Pye R, Torzillo P, Webb S, Wilson M, Ziegenfuss M. Extracorporeal membrane oxygenation for 2009 influenza A (H1N1) acute respiratory distress syndrome. JAMA. 2009;302:1888-95.

12. Noah MA, Peek GJ, Finney SJ, Griffiths MJ, Harrison DA, Grieve R, Sadique MZ, Sekhon JS, McAuley DF, Firmin RK, 
Harvey C, Cordingley JJ, Price S, Vuylsteke A, Jenkins DP, Noble DW, Bloomfield R, Walsh TS, Perkins GD, Menon D, Taylor BL, Rowan KM. Referral to an extracorporeal membrane oxygenation center and mortality among patients with severe 2009 influenza A (H1N1). JAMA. 2011;306:1659-68.

13. Holzgraefe B, Broome M, Kalzen H, Konrad D, Palmer K, Frenckner B. Extracorporeal membrane oxygenation for pandemic H1N1 2009 respiratory failure. Minerva Anestesiol. 2010;76:1043-51.

14. Patroniti N, Zangrillo A, Pappalardo F, Peris A, Cianchi G, Braschi A, Iotti GA, Arcadipane A, Panarello G, Ranieri VM, Terragni P, Antonelli M, Gattinoni L, Oleari F, Pesenti A. The Italian ECMO network experience during the 2009 influenza A (H1N1) pandemic: preparation for severe respiratory emergency outbreaks. Intensive Care Med. 2011;37:1447-57.
15. Roch A, Lepaul-Ercole R, Grisoli D, Bessereau J, Brissy O, Castanier M, Dizier S, Forel JM, Guervilly C, Gariboldi V, Collart F, Michelet P, Perrin G, Charrel R, Papazian L. Extracorporeal membrane oxygenation for severe influenza A (H1N1) acute respiratory distress syndrome: a prospective observational comparative study. Intensive Care Med. 2010;36:1899-905.

16. Takeda S, Kotani T, Nakagawa S, Ichiba S, Aokage T, Ochiai R, Taenaka N, Kawamae K, Nishimura M, Ujike Y, Tajimi K; Committee of Crisis Control, the Japanese Society of Respiratory Care Medicine and Committee of Pandemic H1N1 Surveillance, the Japanese Society of Intensive Care Medicine. Extracorporeal membrane oxygenation for 2009 influenza A (H1N1) severe respiratory failure in Japan. J Anesthesia. 2012. 